\title{
The prevalence and clinical features of depressive syndrome in children with epilepsy in Cipto Mangunkusumo Hospital, Jakarta
}

\author{
Rini Sunarwati, MD; Dwi Putro Widodo, MD; Bambang Madiyono, MD; Willy Edith HP, MD, PhD
}

\begin{abstract}
Background Symptoms of depression often emerge in children with epilepsy, but parents or caregivers are not always able to recognize them.

Objective To assess the prevalence and clinical features of depressive syndrome among pediatric epilepsy patients in Cipto Mangunkusumo Hospital, Jakarta.

Methods This was a cross-sectional study on children aged 818 years. Child Depression Inventory (CDI) was used as the instrument for assessing depressive symptoms.

Results Depressive syndrome was found in 34 out of 89 subjects. The three most frequent depression symptoms were selfdeprecation (via peer comparison), indecisiveness, and pessimism. Frequency of seizures, mode of therapy, and EEG result were important factors in the development of depressive syndrome in children with epilepsy.

Conclusions The prevalence of depressive syndrome in children with epilepsy was $38 \%$. Symptoms of depression mostly found in this study were self-deprecation (via peer comparison), indecisiveness, and pessimism [Paediatr Indones 2004;44:193-196].
\end{abstract}

Keywords: epilepsy, depression, Child Depression Inventory, depressive syndrome

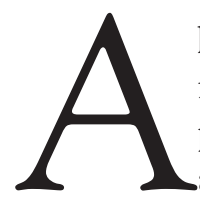

lthough most epilepsy patients can live normally, $20-30 \%$ of them suffer from psychological disorders. ${ }^{1-5}$ Most authors assume that this is associated with uncontrolled seizures. ${ }^{6,2,7-9}$ This condition can lead to psychiatric disturbances including depression, anxiety, and psychosis. ${ }^{3,10,11}$ Depressive disorders often emerge in children with epilepsy, but apparently they are not always recognized by parents or caregivers. ${ }^{6,12}$ Many studies on depression in adult epilepsy patients have been performed but there are less studies in children. ${ }^{13}$ One of these was done by Ettinger who found that $26 \%$ of children with epilepsy have symptoms of depression. ${ }^{14}$

In Indonesia, studies on depression in children with epilepsy had been reported by Haryanto in Yogyakarta and Febriyana in Surabaya. ${ }^{15-16}$ In Jakarta, it has not been performed yet. The main objective of this study was to find out the prevalence and clinical features of depressive syndrome in children with epilepsy in Cipto Mangunkusumo Hospital, Jakarta.

\section{Methods}

This was a cross-sectional study using non-random sampling. Based on statistical calculation, we needed 74 subjects. We used the Child Depression Inventory (CDI) as the instrument for assessing depressive symptoms. The study was performed at the Outpatient Clinic of the Division of Neurology, Department of Child Health and at the Epilepsy Clinic, Department

From the Department of Child Health, Medical School, University of Indonesia, Jakarta, Indonesia.

Reprint requests to: Rini Sunarwati, MD, Department of Child Health, Medical School, University of Indonesia, Cipto Mangunkusumo Hospital, Jakarta, Indonesia. Tel. 62-21-3907740; Fax.3907743. 
of Neurology, Cipto Mangunkusumo Hospital during May until September 2003. Children aged 8-18 years who suffered from epilepsy (defined as recurrent nonfebrile seizures), agreed to give informed consent, and understood CDI after given explanation were included. Patients with mental retardation, incomplete medical records, and cerebral palsy were excluded.

Each patient had to complete CDI which is a self-reporting questionnaire consisting of 27 items that assess symptoms of depression. Each item was scored as follows: $0=$ good, $1=$ moderate, $2=$ bad. Depressive syndrome was defined when the total score was more than or equal to 13. Data were processed using SPSS 10.0 computer program.

Table 1. Distribution of Depressive syndrome ACCORDING TO CLINICAL ASPECTS OF EPILEPSY

\begin{tabular}{|c|c|c|c|}
\hline Variable & $\underset{N}{\mathrm{DS}+}$ & $\underset{N}{D S}-$ & $\mathbf{p}$ \\
\hline \multicolumn{4}{|l|}{ Onset of epilepsy } \\
\hline $0-1$ years & 5 & 7 & 0.701 \\
\hline$\geq 1-5$ years & 7 & 8 & \\
\hline$\geq 5$ years & 22 & 40 & \\
\hline \multicolumn{4}{|l|}{ Frequency of seizure } \\
\hline Everyday & 2 & 1 & 0.030 \\
\hline $1-4 \times$ month & 19 & 20 & \\
\hline $1-4 x /$ years & 12 & 33 & \\
\hline no seizure/years & 1 & 1 & \\
\hline \multicolumn{4}{|l|}{ Seizure type } \\
\hline Generalized & 29 & 38 & 0.129 \\
\hline Partial & 5 & 17 & \\
\hline \multicolumn{4}{|l|}{ Mode of therapy } \\
\hline Polytherapy & 25 & 49 & 0.045 \\
\hline Monotherapy & 9 & 6 & \\
\hline \multicolumn{4}{|l|}{ Length of therapy } \\
\hline$<1$ years & 8 & 16 & 0.316 \\
\hline$\geq 1-2$ years & 3 & 10 & \\
\hline$\geq 2$ years & 23 & 29 & \\
\hline \multicolumn{4}{|l|}{ EEG result } \\
\hline Abnormal & 21 & 45 & 0.047 \\
\hline Normal & 13 & 10 & \\
\hline
\end{tabular}

TABle 2. Multivariate analysis of IMPORTANT VARIABLES

\begin{tabular}{|c|c|c|c|c|}
\hline Variable & b & $p$ & PR & $95 \% \mathrm{Cl}$ \\
\hline $\begin{array}{l}\text { Frequency } \\
\text { of seizures }\end{array}$ & 0.871 & 0.034 & 2.389 & $1.066 ; 5.353$ \\
\hline $\begin{array}{l}\text { Mode of } \\
\text { therapy }\end{array}$ & 1.369 & 0.026 & 3931 & $1.1820 ; 13.072$ \\
\hline EEG result & -1.341 & 0.011 & 0.249 & $0.085 ; 0.730$ \\
\hline
\end{tabular}

\section{Results}

There were 89 subjects aged $8-18$ years included in this study. Boys and girls were almost equal in number. Thirty-three $(37 \%)$ children were $8-12$ years old and 56 (63\%) were 13-18. They were attending elementary, junior high, and senior high schools. Parental education varied from uneducated to university graduated; most were senior high school graduated. More than half of the mothers were housewives, while the fathers mostly worked as private employees. Family income varied from less than 500,000 rupiahs per month to more than 3 million rupiahs.

According to the CDI questionnaire which was implemented once, 34 subjects suffered from depressive syndrome. Mild depression score (13-17) was noted in 20 subjects, moderate (18-23) in 9 subjects, and severe (24-54) in 5 subjects. Table 1 shows the distribution of subjects in the depression and non-depression groups based on clinical aspects of epilepsy.

Multivariate analysis showed that frequency of seizures, mode of therapy, and EEG result were important factors in the development of depression in epilepsy patients (Table 2).

There are 27 specific items about depression in CDI. The frequency of each item in children with epilepsy is listed in Table 3. We noted that the most frequent symptoms of depression were selfdeprecation, indecisiveness, and pessimism. There were only 9 items in CDI which were not qualified as significant symptoms for depression $(\mathrm{p}>0.05)$. Table 3 also provides information about positive likelihood ratio (PLR). Sadness, self deprecation, crying spells, loneliness, and feeling unloved were symptoms of depression which had high scores (between 4 and 10.6).

\section{Discussion}

Epidemiological studies on depression in epileptic patients showed various results due to different methodology. ${ }^{13}$ Some considered depression as symptoms, others as a disease entity. Most subjects were adult patients. Studies on depression in epileptic children were rare. Ettinger reported that the prevalence of depression based on CDI in 
TABLE 3. Distribution OF DEPRESSIVE SYMPTOMS IN BOTH GROUPS AND THE POSITIVE LIKELIHOOD RATIO OF EACH ITEM OF CDI

\begin{tabular}{|c|c|c|c|c|c|}
\hline & Depressive symptoms & $\begin{array}{c}\text { DS - } \\
\text { n }\end{array}$ & $\begin{array}{c}\mathrm{DS}+ \\
\mathrm{n}\end{array}$ & p & PLR \\
\hline 1. & Sadness & 2 & 13 & 0.000 & 10.6 \\
\hline 2. & Pessimism & 31 & 28 & 0.013 & 1.5 \\
\hline 3. & Self deprecation & 4 & 14 & 0.000 & 5.6 \\
\hline 4. & Anhedonia & 14 & 23 & 0.000 & 2.6 \\
\hline 5. & Negative self esteem & 7 & 11 & 0.032 & 2.6 \\
\hline 6. & Pessimistic worrying & 17 & 16 & 0.175 & 1.5 \\
\hline 7. & Self-hate & 3 & 6 & 0.080 & 3.2 \\
\hline 8. & Self-blame & 24 & 21 & 0.127 & 1.4 \\
\hline 9. & Suicidal ideation & 14 & 16 & 0.041 & 1.8 \\
\hline 10. & Crying spells & 3 & 10 & 0.004 & 5.3 \\
\hline 11. & Irritability & 8 & 12 & 0.035 & 2.4 \\
\hline 12. & Reduced social interest & 12 & 13 & 1.144 & 1.8 \\
\hline 13. & Indecisiveness & 33 & 29 & 0.017 & 1.4 \\
\hline 14. & Negative body image & 25 & 25 & 0.015 & 1.6 \\
\hline 15. & School-work difficulty & 16 & 18 & 0.042 & 1.8 \\
\hline 16. & Sleep disturbance & 12 & 21 & 0.000 & 2.8 \\
\hline 17. & Fatigue & 8 & 11 & 0.06 & 2.2 \\
\hline 18. & Reduced appetite & 10 & 14 & 0.063 & 2.3 \\
\hline 19. & Somatic concerns & 31 & 76 & 0.070 & 1.4 \\
\hline 20. & Loneliness & 7 & 18 & 0.000 & 4.2 \\
\hline 21. & School dislike & 21 & 19 & 0.127 & 1.5 \\
\hline 22. & Lack of friends & 10 & 20 & 0.000 & 3.1 \\
\hline 23. & School performance decrement & 24 & 24 & 0.017 & 1.6 \\
\hline \multirow[t]{2}{*}{24.} & Self-deprecation & & & & \\
\hline & (via peer comparison) & 25 & 34 & 0.028 & 2.2 \\
\hline 25. & Feeling unloved & 6 & 15 & 0.001 & 4.0 \\
\hline 26. & Disobedience & 18 & 16 & 0.187 & 1.4 \\
\hline 27. & Fighting & 4 & 9 & 0017 & 3.6 \\
\hline
\end{tabular}

epileptic children was $26 \% .{ }^{14}$ In this study, we also used CDI and revealed prevalence as high as 38\%.

Among 34 subjects who had depressive syndrome, 20 were categorized as mild, which had good prognosis, 9 moderate, and 5 severe. ${ }^{15}$ Demographic data showed similarities between subjects with and without depressive symptoms. Clinical aspects of epilepsy that influenced depression were frequency of seizures, mode of therapy, and EEG result. Seizures occurring 1-4 $\mathrm{x} /$ month and polytherapy were more influential compared to EEG result. Abnormality of EEG is a common finding in epileptic patients without depression though further studies are necessary to explain this condition.

Subjects with depressive syndrome were more likely to answer self-deprecation (via peer comparison) (34/34), indecisiveness (29/34), and pessimism (28/34). These three items are unspecific symptoms of depression and had low positive likelihood ratio $(<4)$. In depression-free subjects, these were also frequently obtained. Symptoms with high positive likelihood ratio were sadness, self-blame, crying spells, loneliness, and feeling unloved.

There were also some limitations in our study. CDI is a self-reporting questionnaire and was implemented only once. We did not perform any specific anamnesis to examine the mental status of the patients, so that they could not freely express their own feelings. Because this was a hospital study, the results could not represent the condition in general population. Another limitation was that we recruited subjects by non-random sampling.

We conclude that prevalence of depressive syndrome in children with epilepsy in Cipto Mangunkusumo Hospital is 38\%. Symptoms of depression mostly found are self-deprecation (via peercomparison), indecisiveness, and pessimism.

\section{References}

1. Apriwanto T, Husni A. Kualitas hidup penyandang epilepsi tipe granmal usia dewasa. Medika 1998;24:641-7.

2. Baker GA, Jacoby A, Buck D, Stalgis C, Monet D. Quality of life of people with epilepsy: European study. Epilepsia 1997;38:353-62.

3. Mendez MF. Neuropsychiatric aspects of epilepsy. In: Sadock BJ, Sadock VA, editors. Comprehensive textbook of psychiatry. $7^{\text {th }}$ ed. Philadelpia: Lippincott Williams \& Wilkins; 2000. p. 261-72.

4. Cumming JL, Trimble MR. Neuropsychiatry and behavioral neurology. Washington DC: American Psychiatry Press Inc; 1995. p. 121-31.

5. Dodril CB. Correlates of generalized tonic seizures with intellectual, neuropsychological, emotional, and social function in patient with epilepsy. Epilepsia 1986; 37:399-41

6. Oostrom KJ, Schouten A, Olthof T, Peters AL Schinkel. Negative emotion in children with newly diagnosed epilepsy. Epilepsia 2000;41:326-31.

7. Chadwick D. Epilepsy. J Neurol Neurosurg Psychiatry 1994;57:264-77.

8. Van Hout B, Gognon D, Souctre E, Ried S, Remy C, Baker $\mathrm{G}$, et al. Relationship between seizure frequency and cost and quality of life of outpatients with partial epilepsy in France, Germany, and United Kingdom. Epilepsia 1997;38:1221-6.

9. Trimble MR. Behavioral and cognitive issues in childhood epilepsy. In: Dodson WE, Pellock JM, editors. Pedi- 


\section{Paediatrica Indonesiana}

atric epilepsy: diagnosis and therapy. New York: Demos; 1993. p. 387-407.

10. Torta R, Keller R. Behavioral, psychotic and anxiety disorders in epilepsy: Etiology, clinical features and therapeutic implications. Epilepsia 1999;40:S2-20.

11. Victoroff J, Benson F, Grafton S, Engel J, M Azziotta JC. Depression in complex partial seizures. Electroencephalography and central metabolic correlates. Arch Neurol 1994; 51:155-63.

12. Suryo L, Kusumawardhani AAAA. Depresi pada epilepsi. Jiwa Indon Psychiat Quart 1996;29:47-56.
13. Lambert MV, Robertson MM. Depression in epilepsy: etiology, phenomenology and treatment. Epilepsia 1999;40:S21-47.

14. Ettinger AB, Weibrot DM, Nolan E, Gadow KD, Vitale SA. Symptoms of depression and anxiety in pediatrics epilepsy patient. Epilepsia 1998;39:595-9.

15. Febriyana N, Lestari BS, Suksmi Y, Saharso D. Faktorfaktor yang mempengaruhi depresi pada anak penyandang epilepsi grand mal. Jiwa 2003;36:9-20.

16. Haryanto B. Gangguan perilaku pada epilepsi dan faktor faktor yang mempengaruhi [thesis]. Yogyakarta: Medical School Gajah Mada University; 1995. 